Free Market

Economics 


\title{
Free Market Economics
}

\author{
A Critical Appraisal
}

\section{ANDREW SCHOTTER}

Associate Director, C. V. Starr Center for Applied Economics at New York University

Macmillan Education 


\section{For Anne}

ISBN 978-1-349-08130-1 ISBN 978-1-349-08128-8 (eBook)

DOI 10.1007/978-1-349-08128-8

Copyright $(1985$ by St. Martin's Press, Inc.

All rights reserved. For information, write:

St. Martin's Press, Inc., 175 Fifth Avenue, New York, NY 10010

Printed in the United States of America

First published in the United States of America in 1985

ISBN 978-0-312-30369-3

cover design: Darby Downey

text design: Darby Downey

Library of Congress Cataloging in Publication Data

Schotter, A.

Free market economics.

Bibliography: p. 137

Includes index.

1. Laissez-faire. I. Title.

HB95.S36 1985

$330.15^{\prime} 3$

84-8217

ISBN 978-0-312-30369-3

ISBN 978-0-312-30370-9 (pbk.) 


\section{Preface}

From listening to my students and to people at cocktail parties talk about the free market system, I have come to realize that there is a great deal of misunderstanding about the free market argument. The world seems divided between people who see markets as the cure for all our problems and people who see markets as the cause of all problems.

This book takes the view that the truth lies somewhere in between. In it I attempt to apply the free market argument to a wide variety of social issues and, in doing so, to point out some of its contradictions. However, my aim is not so much to discount free market economics as to raise doubts about its validity as a solution for all social problems. The criticisms I present are immanent; that is, they do not challenge the assumptions upon which the free market argument is based but rather accept them and use them to demonstrate how they can lead to social outcomes unacceptable to a consistent free market advocate. I conclude that while markets do work in many situations, they are not panaceas, and for some problems non-market institutions may be preferable. These institutions should be organized and coordinated by the state because private incentives fail to create and control them.

This book is addressed to many audiences. First, it has 
been written as a supplement to the textbooks used in a number of economics courses taught at universities. Any course that uses competitive (free market) economics as its theoretical foundation would benefit from devoting time to the ideas presented here. Such courses include not only economic principles (both micro and macro) but also intermediate microeconomics and industrial organization. Other courses where this book may be useful are economics of public policy, welfare economics, and business school courses on the nature of the competitive process. Students-and, for that matter, professors-should be forced to stop and think about the subtleties of the economic arguments they use to buttress their classroom discussion and policy analysis. Few books are available that do this in a logical, non-polemical way, using modern economic ideas. This is what I attempt here.

In addition, I hope that this book will be read by intelligent laymen, policy makers, and political leaders willing to follow a logically rigorous, but generally non-mathematical, argument to its conclusion. I feel that the current social debate treats the theory of free markets in much too cavalier a manner, invoking it to justify policies without proving that such an invocation is appropriate. If there were a better understanding of the limitations of the free market argument, a more rational public policy debate might follow.

This book progresses from the general to the specific. In chapter 1, I describe the "free market economic argument," spelling out its basic assumptions and tracing their roots in the history of economic thought. Chapter 2 presents conventional criticisms of the argument, which, since few of them are immanent, are not pursued in the remainder of the book. In chapter $3 \mathrm{I}$ give examples to demonstrate the benefit of organizing society along free market lines. Chapter 4 aims at pinpointing where the free market system can break down, showing how individual rationality - the cornerstone of the free market argument-is responsible for many of the system's failures. As an illustration, I review some new and some traditional instances of markets that fail to determine optimal social outcomes, reviewing work on markets with what are known as informational asymmetries, externalities, and 
public goods. Here the selfish individual rationality of the agents in the market destroys its results instead of leading, "as if by an invisible hand," to socially desirable outcomes. Chapter 5 then shifts us from the realm of theory to that of policy. It investigates such public-policy issues as crime, minimum wages, affirmative action, anti-discrimination laws, and educational vouchers. Chapter 6 presents a theory of justice that should be acceptable to people who subscribe to the free market ideals spelled out in chapter 1 , but that may lead to outcomes that they would find undesirable. Chapter 7 looks at the most recent and the strongest assumption of rationality used in the free market argument-the assumption of rational expectations-and points out potential logical difficulties with it that, if true, would dramatically alter many of the recent macro-economic policy conclusions reached by the leaders of the rational expectations school. Chapter 8 offers reasons for the endurance of the free market system in America. Chapter 9 summarizes the discussion and offers conclusions. I hope that by the time the reader reaches this point, he will have gained a more detached and objective view of the pros and cons of free market economics.

Because there are many potential audiences for this book, there are many ways to read it. General readers interested in a quick overview of the book's argument should read chapters $1,3,4,5$, and 9. Professors planning to assign the book, however, should use a more sophisticated strategy geared to the course being taught and the background of the students. Chapters 3,8 , and 9 are the least difficult and require no background in economics. Chapters $1,2,4,5$, and 6 require exposure to introductory economics-for example, through the economic principles course. Chapter 7 calls for an intermediate amount of knowledge of economics and related disciplines. This chapter is by far the most difficult in the book and should only be assigned in more advanced undergraduate or beginning graduate courses. As for the material presented in the other chapters, however, I believe that any diligent undergraduate should have no difficulty in understanding it. Chapters 1,2 , and 3 should be read by all students, regardless of the course in which they are enrolled, while the other 
chapters can be selected according to the emphasis of a specific course. Except for Chapter 7, this book uses no mathematics whatsoever. Nevertheless, the analysis is still logically rigorous and possibly demanding at points. I have made it so in order to give beginning students something to strive for, while at the same time not insulting more advanced students.

When an earlier version of this book, entitled "Capitalism and Corner Solutions: Some Problems with the Conservative Argument," was circulated among my friends and colleagues at New York University, they made me realize that what I was discussing in that somewhat polemical manuscript was not the conservative argument-which has distinct political, philosophical, and even religious overtones-but rather the more libertarian free market argument. Hence, I wish to thank Jess Benhabib, Clive Bull, Ray Canterbery, Roman Frydman, Lewis Kornhauser, Janusz Ordover, Peter Rappoport, Mark Schankerman, and Bernard Wasow for the frankness of their comments on that manuscript, a frankness that led me to make drastic changes in this book over the past two years. I would yet again like to thank Clive Bull and Lewis Kornhauser for their comments on selected chapters of the final manuscript. I want to acknowledge my debt to the work of Roman Frydman and Gerald O'Driscoll in the discussion of Newcomb's problem in chapter 7. Also, I wish to thank my editor, Michael Weber of St. Martin's Press, for his encouragement and patience and for providing me with some excellent (anonymous) referee reports that made my revisions easier. As with all of my work, this book was made possible in part by the support of the Office of Naval Research, Contract No. N00 14-78-C-0598. This support is gratefully acknowledged. Finally, I thank my wife, Anne Howland Schotter, for her careful stylistic editing. 


\section{Contents}

Preface v

1 The Free Market Argument 1

2 Standard Criticisms of the Free Market Argument 17

3 Why Are Free Markets So Good? 39

4 Rationality and Market Failure 47

5 Free Market Policy Prescriptions 65

6 Blame-Free Justice 89

7 Rational Expectations and Newcomb's Problem 101

8 Why Is the American Free Market System So Stable? 119

9 Conclusion 131

Glossary 133

Bibliography 137

Index 143 


\section{Free Market}

Economics 